\title{
Model ekonomii współpracy w koncepcji miast Smart City 3.0
}

\section{Model of Sharing Economy in the Smart City 3.0 Concept}

Streszczenie: Celem niniejszego artykułu było rozpoznanie nowych możliwości i obszarów rynku dla przedsiębiorczości wykorzystującej współczesne technologie komunikacyjne oraz rozwiązania organizacyjne mieszczące się w ramach pojęcia ekonomii współpracy. Celem stało się również skonfrontowanie tych obszarów z modelem miasta inteligentnego (Smart City). W związku z deskryptywnym charakterem artykułu zaprezentowano w nim przykłady obszarów działalności podmiotów gospodarczych ekonomii współpracy. Naszkicowano rolę tego typu ekonomii w rozwoju miast, a także jej znaczenie we wdrażaniu koncepcji miasta inteligentnego. Zarysowany został także stojący przed włodarzami miast oraz regulatorami problem dynamicznego rozwoju ekonomii współpracy (sharing economy - inne tłumaczenie na język polski to ekonomia współdzielenia). Stanowi on problem, gdyż ze względu na swój charakter i wykorzystywane kanały komunikacji w wymianie rynkowej (aplikacje, serwisy społecznościowe, smartfony) pozostaje poza pełną kontrolą. Podmioty działające według zasad ekonomii współpracy stanowią rosnącą konkurencją dla przedsiębiorców działających w tradycyjnych strukturach organizacyjnych i podlegających regulacjom prawnym oraz fiskalnym. Początkowo niedostrzegany alternatywny rynek usług opartych na komunikacji internetowej w wielu przypadkach rozrósł się i zdominował tradycyjne usługi, np. w centrach miast. Cele artykułu realizowane są przez przegląd literatury i doniesień internetowych - ze względu na specyfikę tematu najbardziej aktualnych źródeł informacji. W artykule treść uzupełniana jest własnymi obserwacjami autora.

\begin{abstract}
The aim of the article is to recognise the new opportunities for entrepreneurship and services development based on new technologies, application, Internet solutions, participatory culture of WEB 2.0 and to confront them with the Smart City concept. Due to the descriptive character of the article, the classification of these services will be presented together with the outline of their role in urban development, as well as the role in the implementation of the Smart City concept. The article touches upon the problem facing the city authorities and regulators, i.e. development of the sharing economy. It is a problem as due to its nature and the channels of market communication used by it, it remains beyond full control. It is also competitive for entrepreneurs operating in traditional organisational structures. Initially unnoticed, alternative services market based on Internet communication in many cases has spread and dominated traditional services, e.g. in city centres. The goals of the article is implemented through a review of literature and Internet reports - due to the specificity of the topic, the most current source of information. The content is supplemented with the author's own observations.
\end{abstract}


Słowa kluczowe: ekonomia współpracy; miasto; rozwó; Smart City; studia miejskie; usługi

Keywords: city; development; services; sharing economy; smart city; urban studies

Otrzymano: 7 lutego 2019

Received: 7 February 2019

Zaakceptowano: 12 sierpnia 2019

Accepted: 12 August 2019

Sugerowana cytacja/Suggested citation:

Rudewicz, J. (2019). Model ekonomii współpracy w koncepcji miast Smart City 3.0. Przedsiębiorczość

- Edukacja [Entrepreneurship - Education], 15(2), 153-170. doi: 10.24917/20833296.152.11

\section{Wstęp}

Przyczynkiem do powstania artykułu była zauważalna coraz wyraźniej w doniesieniach z literatury naukowej i prasy ekonomicznej obecność w miastach przedsiębiorstw działających w obszarze ekonomii współpracy (sharing economy). Temu trendowi towarzyszy równolegle inny trend. Jesteśmy bowiem świadkami powolnej jeszcze realizacji projektów związanych z popularną na świecie wizją miast inteligentnych (Smart City). Wokół tej problematyki organizowanych jest wiele konferencji i spotkań przedstawicieli przemysłu i usług ICT z włodarzami miast, ekspertami i naukowcami. W artykule zakłada się, że miasto inteligentne jest miejscem sprzyjającym dla rozwoju mechanizmów ekonomii współpracy, a wizja Smart City stwarzać będzie do tego odpowiednie warunki techniczne. Celem artykułu jest zatem skonfrontowanie tych dwóch nowych trendów w miastach i odnalezienie wspólnych obszarów dla obu konceptów. Smart City to koncepcja odnosząca się stricte do miast, natomiast ekonomia współpracy ma szerszy zasięg, jednak jej naturalnym środowiskiem i miejscem inkubacji jest miasto, metropolia i jej kreatywni świadomi mieszkańcy.

Artykuł ma charakter deskryptywny, dlatego dla realizacji założonych w nim celów zastosowano metodę przeglądu literatury. W artykule postawiono kilka pytań badawczych:

- Na czym polegają fenomen i mechanizmy działania gospodarki współpracy?

- Jakie są obszary rynku, w których możliwe jest zaistnienie mechanizmów typowych dla gospodarki współpracy?

- Czy istnieją obszary działalności gospodarczej ekonomii współpracy korespondujące $\mathrm{z}$ wizją miasta inteligentnego?

- Jakie bariery napotyka gospodarka współpracy w miastach i jak zmienia ona lokalną gospodarkę?

Wprowadzenie do problematyki poruszanej w artykule wymaga podbudowy teoretycznej i ustalenia aparatu pojęciowego. Pierwszym krokiem jest zatem wyjaśnienie, czym jest wizja miasta inteligentnego Smart City. Kolejne działanie to próba wyjaśnienia istoty ekonomii współpracy. Inteligentne miasta i ekonomia współpracy składają się z różnych elementów, to złożone koncepty o rozmytych granicach definicyjnych. Obu opisywanym $\mathrm{w}$ artykule konceptom brakuje powszechnie uzgodnionych definicji i często definiuje się je przez listę cech, a nie przez kompleksową, zwięzłą definicję. Wynika to z trudności opisu współczesnego świata, a w szczególności stosunkowo nowych zjawisk. Zarówno Smart City, jak i sharing economy to zjawiska interesujące naukowców zajmujących się w swej pracy studiami miejskimi, ekonomią, zarządzaniem i marketingiem, a także socjologów, geografów ekonomicznych i badaczy kultury. Zainteresowane są nie tylko kręgi naukowe - dołączają do nich biznesmeni i praktycy zarządzania miastami. 
Smart City 3.0 - aparat pojęciowy

Definicji miasta inteligentnego w literaturze jest bardzo wiele. Zainteresowani zestawienia klasyfikujące i systematyzujące definicje w wielu opracowaniach np. w artykule pt. Unified Definition of a Smart City (Ramaprasad, Sánchez-Ortiz, Syn, 2017), czy też opracowaniu pt. Smart cities: definitions, dimensions, and performance (Albino, Berardi, Dangelico, 2015). Krytycznej analizy pojęcia dokonali także badacze włoscy w publikacji Smart City: fact and fiction (De Santis i in., 2014). Kwestie definicji miasta inteligentnego komplikują również orbitujące wokół niej wizje i koncepcje miast zawierające komponenty nowoczesności, rozwoju technologicznego oraz cyfryzacji, tj.: miasto cyfrowe (Digital City), miasto kreatywne (Creative City), miasto wiedzy (Knowledge City), miasto wirtualne (Virtual City), miasto usieciowione [przyp. tłum.] (ubiquitous city, u-City) (Ishida, 2017).

W sprzeczności z koncepcją Smart City nie stoją również koncepcje miast o szerszych holistycznych założeniach teoretycznych, m.in. miasta wysokiej jakości życia XXQ, Eco-City, Green-City, Livable City, Compact City oraz miasta zrównoważonego rozwoju (Mierzejewska, 2015). Zatem koncepcja Smart City jest jedną z wielu współczesnych koncepcji rozwoju miast. Ze względu na istniejące duże możliwości biznesowe zarówno dla korporacji z branży ICT, jak i mniejszych podmiotów (Information and Communication Technologies) oraz znaczne możliwości poprawy efektywności funkcjonowania miejskich systemów pod względem ekonomicznym, wydajnościowym i jakościowym budzi ona coraz większe zainteresowanie na świecie. Koncepcja Smart City nie wyklucza założeń pozostałych koncepcji miejskich. Różni się jedynie większym zaangażowaniem technologii w celu stworzenia miast opisywanych postulatami innych koncepcji. Z tego powodu jest to bardziej operacyjny pomysł na miasto, zawierający połączone komponenty związane z technologią oraz komponent społeczny. Wizja miasta inteligentnego łączy je wszystkie ze sobą. Inteligentne miasto to miasto, w którym wykorzystuje się technologie informacyjno-komunikacyjne ICT w celu zwiększenia interaktywności i wydajności infrastruktury miejskiej i jej komponentów składowych, a także do podniesienia świadomości mieszkańców. Miasto może być traktowane jako „inteligentne”, gdy podejmuje inwestycje w kapitał ludzki i społeczny oraz infrastrukturę komunikacyjną w celu aktywnego promowania zrównoważonego rozwoju gospodarczego i wysokiej jakości życia, w tym mądrego gospodarowania zasobami naturalnymi, przez partycypację obywatelską (Azkuna, 2012).

Grupa firm doradczych Smart City Council wskazuje trzy podstawowe charakterystyczne cechy miast Smart City:

- komfort życia (livability) - miasta, które zapewniają zdrowe warunki życia, ograniczają zanieczyszczenia środowiska i kongestię miejską. Dzięki cyfrowej infrastrukturze usługi miejskie są dostępne natychmiastowo, zawsze i wszędzie;

- sprawność (workability) - miasta, które mają infrastrukturę umożliwiającą dostawy energii, łączność, internet. Są przez to konkurencyjne i zapewniają wysokiej jakości miejsca pracy;

- zrównoważenie (sustainability) - miasta, które dbają o zasoby naturalne i wdrażają ideę rozwoju zrównoważonego (Smart Cities Council, 2019).

Wzrost popularności tej koncepcji koreluje z pojawieniem się i upowszechnieniem łączności szerokopasmowej LTE i w niedalekiej przyszłości szybkich standardów łączności 5G (LTE standard bezprzewodowego przesyłu danych czwartej generacji, 5G jest 
następcą LTE) oraz urządzeń mobilnych. Mieszkańcy miast sami demokratycznie decydują o stopniu wykorzystania technologii w życiu miasta. Kwestie upowszechnienia technologii i transmisji danych mogą naturalnie budzić opór i obawy, np. w sprawach dotyczących danych osobowych oraz możliwości kontroli i inwigilacji przez podmioty i organizacje związane z marketingiem, bezpieczeństwem oraz cyberprzestępców. Pomimo obaw rozwiązania informatyczne upowszechniają się i odgrywać będą coraz większą rolę w codziennym życiu i kulturze oraz gospodarce, zastąpią „analogowy świat”.

B. Cohen, znana postać dla osób interesujących się tematem rozwoju miast, zaprezentował trzy etapy wdrażania koncepcji Smart City (Cohen, 2015). Pierwsze dwa dotyczą sposobu implementacji wizji miasta inteligentnego, przy czym w pierwszym wiodącą rolę odgrywają koncerny ICT, w drugim - władze miejskie. Wadą tych dwóch stadiów rozwoju miast inteligentnych jest marginalizowanie roli mieszkańców we współtworzeniu swojego miejsca zamieszkania i pracy. Najpowszechniejsza jest obecnie generacja Smart Cities 3.0 (Citizen Co-Creation). Charakteryzuje się ona tym, że kluczową rolę $\mathrm{w}$ rozwoju miast przejmują ich obywatele. $\mathrm{W}$ tej generacji właśnie łączy się wymiar społeczny z wymiarem cyfrowym. Smart Cities 3.0 to coś znacznie więcej niż np. standardowe procedury budżetu obywatelskiego, oddające decyzję o ułamku budżetu miasta w ręce mieszkańców. W miastach inteligentnych trzeciej generacji mieszkańcy sami współtworzą swoje miasta. Przykładami tego typu miast są: Wiedeń, Vancouver, a także kolumbijskie miasto Modelin, co pokazuje, że tego typu miasta nie muszą znajdować się w państwach wysokorozwiniętych. W generacji Smart Cities 3.0 znaczącą rolę odgrywają projekty o charakterze społecznym, równościowe, z zakresu inkluzji społecznej, taniego budownictwa, partycypacji itp. Odpowiednie miejsce ma w tej koncepcji ekonomia współpracy (współdzielenia, gospodarka dzielenia się) (Deloitte, 2015). W doniesieniach prasowych i źródłach internetowych (2019) pojawia się już opis generacji Smart City 4.0. Łączy ona pojęcie przemysłu Industry 4.0 i Smart City, nie ma jednak związku z generacjami opisywanymi wyżej.

W tabeli 1 przedstawiono podstawowe obszary funkcjonalne inteligentnych rozwiązań dla miast. Zestawienie to, znane jako model Giffingera, zostało stworzone dla celów analizy wskaźnikowej miast, służącej pozycjonowaniu miast pod względem bycia „smart” (Giffinger, 2010). Jak możemy zauważyć, wyszczególnione obszary dotyczą wielu sfer funkcjonowania miast, od typowo technicznych i inżynieryjnych, do poziomu miejskich społeczności.

Na podstawie powyższego modelu cytowany już Cohen zbudował inny, bardziej szczegółowy model opisowy: Smart City Wheel - koło miasta inteligentnego. W wewnętrznym okręgu znajdują się obszary funkcjonalne z modelu Giffingera: inteligentna gospodarka, inteligentne środowisko, inteligentne zarządzanie, inteligentne życie, inteligentna mobilność oraz inteligentni ludzie. W zewnętrznym kole znalazły się kategorie bardziej szczegółowe, np. w obszarze: inteligentna gospodarka podkreślana jest wydajność, powiązania lokalne i globalne oraz poszerzenie możliwości gospodarczych. Zewnętrzny pierścień w kole miasta inteligentnego tworzą towarzyszące kategoriom szczegółowym działania i wskaźniki. Autor tego modelu dokonał analizy kategorii wskazanych w swoim modelu w kilkunastu miastach za pomocą 62 wskaźników. Czołową dziesiątkę stworzyły miasta: Barcelona, Kopenhaga, Helsinki, Singapur, Vancouver, Wiedeń, Birsbane, Los Angeles, Bogota i Lima. W rankingu znalazły się miasta zarówno z grupy państw wysokorozwiniętych, jak i tych wkraczających na ścieżkę rozwoju. 
Tabela 1. Podstawowe obszary funkcjonalne rozważań nad Smart City wg Vienna University of Technology. Model Giffingera

1. Smart Economy (inteligentna gospodarka) - konkurencyjność, innowacyjność, produktywność, przedsiębiorczość, elastyczność rynku pracy, inwestycje międzynarodowe, zaangażowanie kapitałowe

2. Smart Mobility (inteligentna mobilność) - dostęp do nowoczesnych technologii informacyjnych i komunikacyjnych oraz zrównoważone systemy transportowe, zarówno lokalne, międzymiastowe, jak i międzynarodowe

3. Smart Environment (inteligentne środowisko) - atrakcyjność walorów przyrodniczych, ochrona środowiska i zarządzanie zasobami naturalnymi, stopień zanieczyszczenia środowiska, świadomość ekologiczna

4. Smart People (inteligentni ludzie) - poziom kwalifikacji i edukacji obywateli, zdolność do podnoszenia kwalifikacji, kreatywność, jakość interakcji społecznych, otwartość na świat zewnętrzny, zróżnicowanie społeczne i kulturowe, udział w życiu publicznym

5. Smart Living (inteligentne życie) - kultura, edukacja, kształcenie ustawiczne, warunki bytowe i komfort zamieszkania, bezpieczeństwo osobiste, warunki zdrowotne, integracja społeczna, atrakcyjność turystyczna

6. Smart Governance (inteligentne zarządzanie) - szeroko pojęte funkcjonowanie administracji, transparentność zarządzania, strategie polityczne i perspektywy, uspołecznienie rozwoju

Źródło: Smart cities Ranking of European medium-sized cities (2007: 11-12)

Rycina 1. Smart City Wheel - koło miasta inteligentnego

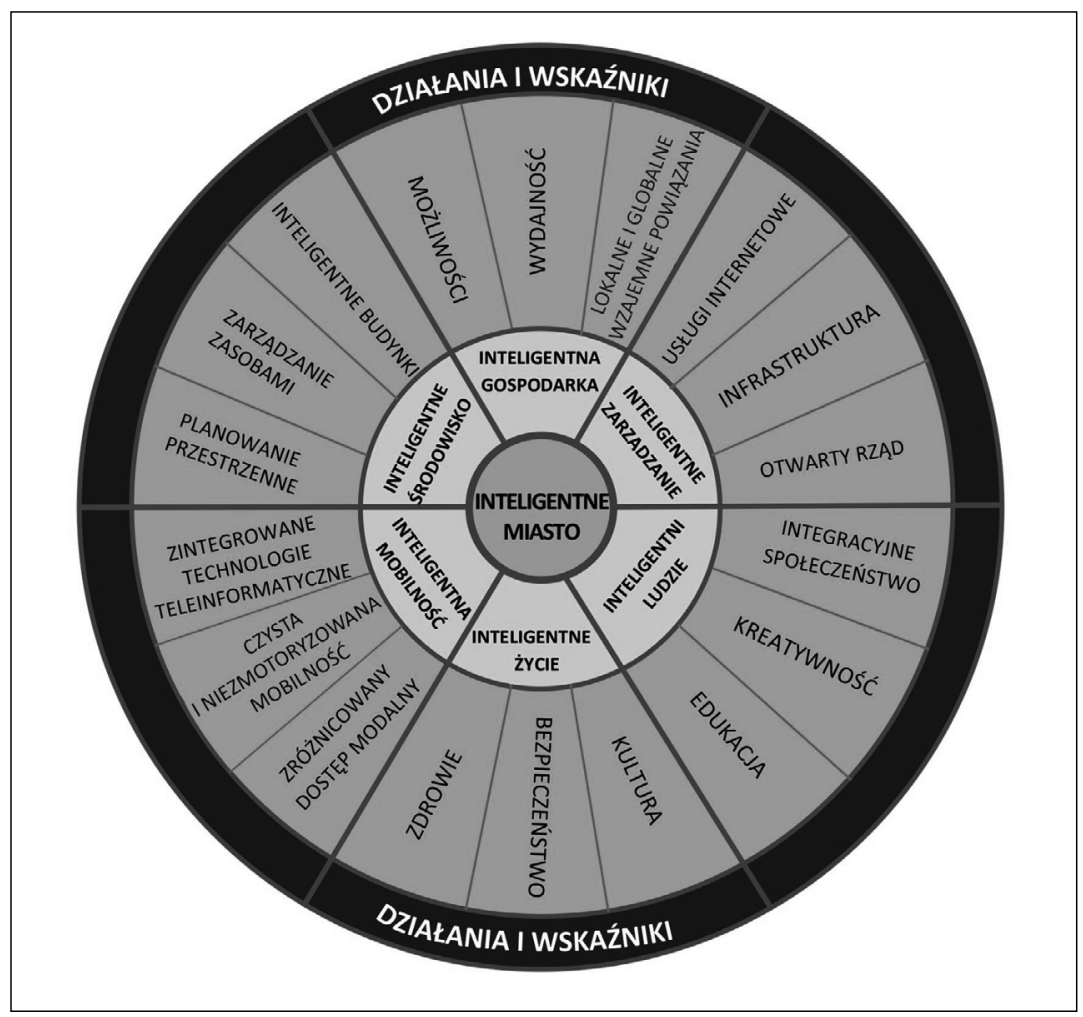

Źródło: Gotlibowska (2018) 
Pozostając przy kwestiach definicyjnych i meritum artykułu, wyjaśnienia wymaga, jak definiowane są działania stosujące komunikację przez internet i aplikacje mobilne oraz jak wygląda społeczny otwarty nadzór nad jakością dóbr i usług. Otóż aktywności te mieszczą się w kategorii ekonomii współpracy - sharing economy.

\section{Sharing economy - podstawowe elementy i warunki}

Podstawą ekonomii współpracy jest współdzielenie. Wykracza ono poza korzyści ekonomiczne uczestników rynku w tradycyjnej wymianie rynkowej. W wymianie dóbr i usług na zasadach ekonomii współpracy zastosowanie ma własny kapitał rzeczowy (trwały i obrotowy), w większości przypadków też własna praca, kreatywność. Nieodzowna w relacjach rynkowych wymiana informacji pomiędzy stroną reprezentującą popyt a stroną reprezentującą podaż odbywa się za pomocą komunikacji internetowej i mediów społecznościowych.

Do tej pory brakuje w literaturze jednolitej definicji ekonomii współpracy. Zamieszczone wyżej bliskoznaczne określenia tego zjawiska społeczno-technologiczno-ekonomicznego wskazują na problem, jaki mają eksperci w jego dookreśleniu. W latach 70 . XX w., jeszcze przed pojawieniem się internetu i urządzeń mobilnych, ten trend zaczęto określać mianem konsumpcji współdzielonej, współkonsumpcji (collaborative consumption) (Stokes i in., 2014). W 2010 r. R. Botsman i R. Rogers opublikowali pierwszą książkę na temat ekonomii współpracy pt. What's Mine is Yours - the rise of collaborative consumption (Botsman, Rogers, 2010). Autorzy zdefiniowali ekonomię współpracy jako tradycyjne dzielenie się dobrami, handel wymienny, wypożyczanie, wynajem, darowiznę dokonywaną za pomocą technologii i istnienia społeczności internetowych. W artykule z 2017 r. pt. Putting the sharing economy into perspective K. Frenken i J. Schor zdefiniowali ekonomię współpracy jako „gospodarkę, w której konsumenci przyznają sobie nawzajem tymczasowy dostęp do rzadko używanych aktywów fizycznych (mocy produkcyjnych), prawdopodobnie za pieniądze”. Autorzy zidentyfikowali też trzy charakterystyczne cechy sharing economy. Były to: interakcja między konsumentami (C2C), tymczasowy dostęp i wykorzystanie dóbr fizycznych (Renker, Schor, 2017:3-10). Nazwa sharing economy w Polsce funkcjonuje najczęściej jako określenie „ekonomia współpracy”, ale spotykana jest też nazwa „ekonomia dzielenia się”, „ekonomia współdzielenia”. Inne nazwy nawiązujące do tego zjawiska spotykane w literaturze w języku angielskim to: collaborative consumption, collaborative economy, on-demand economy, peer-to-peer economy, zero-marginal cost economy, crowd-based capitalism (Selloni, 2017). Ekonomia współpracy i dzielenie się nie są całkowicie nowym zjawiskiem. Tradycyjnie współdzielenie się stanowiło zawsze alternatywę dla kapitalistycznej, nastawionej na zysk gospodarki. Nieformalne sieci współdzielenia i współpracy istnieją w różnych społeczeństwach. Nowość obecnej ekonomii współpracy polega na wykorzystaniu technologii informacyjnych jako kanału wymiany informacji rynkowej i realizacji procesu współdzielenia. P. Munoz i B. Cohen (2017), posiłkując się pracami D. McLarena i J. Agyemana (McLaren, Agyeman, 2015) oraz C.J. Martina (Martin, Upham, Budd, 2015) i R. Chase'a (Chase, 2015), definiują ekonomię współpracy jako „system społeczno-gospodarczy umożliwiający wymianę dóbr i usług między osobami i organizacjami, których celem jest zwiększenie wydajności i optymalizacja niewykorzystywanych zasobów w społeczeństwie”. Zgodnie z tą 
definicją ekonomia współpracy i usługi, które są realizowane w jej ramach, odpowiadają paradygmatowi rozwoju zrównoważonego. Umożliwia się bowiem ponowne użycie wielu dóbr, ich redystrybucję, przedłużenie życia na rynku w cyklu życia produktu. Ekonomia współpracy oraz jej model organizacyjny i dystrybucyjny dają szansę wielu osobom, które pomimo kompetencji mają utrudniony start w tradycyjnej działalności gospodarczej (usługowej) podlegającej regulacjom i nadzorowi państwa. Sharing economy zagospodarowuje aktywność części tych osób, które należały do szarej strefy. Są to np. imigranci, studenci, emeryci, osoby bezrobotne.

Spełnia się tu zatem postulat zawarty w opisie generacji Smart City 3.0. Postulat mówiący o społecznej inkluzji, włączaniu mieszkańców, w tym przypadku w aktywność zawodową. Pośrednio wzmacnia się interakcje społeczne i umożliwia wydajniejsze wykorzystanie zasobów oraz wytworzonych dóbr. Ekonomia współpracy przyczynia się do wyrównywania szans, dając dostęp do niewykorzystanych zasobów za ułamek kosztów tym, którzy nie mogą lub nie chcą kupować nowych produktów. Daje szansę na dodatkowy dochód dla tych, którzy już mają takie niewykorzystane zasoby. Ekonomia współpracy jest postrzegana jako instrument w stawianiu czoła problemom, takim jak nadkonsumpcja i nierówność dochodów.

Działalność gospodarcza oparta na współdzieleniu ewoluowała od prostych inicjatyw pożyczkowych do złożonych platform i sieci łączących osoby oraz przedsiębiorstwa w celu współdziałania i zbiorowego wykorzystania istniejących lub nowych zasobów pracy, ziemi i kapitału. Geneza tego zjawiska ekonomicznego to zbieg kilku czynników. W literaturze wskazuje się, że były to: globalny kryzys ekonomiczny z 2008 r., pojawienie się szybkiego internetu, zmiana generacji sposobu komunikacji w sieci na WEB 2.0 (social media), wzrost zainteresowania kwestiami ochrony środowiska i zrównoważonego rozwoju oraz w pewnym stopniu renesans myślenia kategoriami wspólnoty w miastach. Ekonomia współpracy będąca stosunkowo nowym zjawiskiem nie została jeszcze opisana sztywnymi ramami definicji i klasyfikacji działalności gospodarczej. Według założeń do badań przeprowadzonych przez Munoza i Cohena (Munoz, Cohen, 2015) nad modelem biznesowym oraz pojawiających się kierunków myślenia w ekonomii współpracy zidentyfikowano siedem różnych warunków ją charakteryzujących. Są to:

1. Wykorzystywanie platformy komunikacji w internecie (online marketplaces).

2. Wykorzystywanie niewykorzystanych zasobów.

3. Interakcje peer-to-peer.

4. Współrządzenie (governance).

5. Poczucie misji.

6. Alternatywne źródła finansowania.

7. Zależność od technologii.

Zasadniczą kwestią w rozważaniach nad ekonomią współpracy jest powiązanie współdzielenia z działalnością komercyjną. Największe korporacje globalne działające na bazie platform (online marketplaces), jakimi są strony internetowe i aplikacje, to np. Airbnb i Uber. Są to przedsięwzięcia komercyjne, nastawione na zysk. Pomimo tego spełniają kryteria przynależności do sharing economy. R. Botsman (Botsman, 2015) uważa, że sharing economy to pojęcie często niesłusznie odnoszone do rozwiązań biznesowych opartych na efektywnym kojarzeniu popytu z podażą, które jednak nie uwzględniają ani dzielenia się, ani współpracy. Dlatego zbyt często naużywa się kategorii przynależności do sektora sharing economy; aplikacja mobilna, sprawny algorytm i system płatności to za 
mało. Botsman proponuje pięć warunków, które muszą spełniać przedsiębiorstwa, aby można je było uznać za należące do ekonomii współpracy:

1. Rdzeń biznesu przedsiębiorstwa powinien opierać się na obrocie dobrami nieużywanymi bądź nie w pełni wykorzystanymi - dla korzyści materialnych lub niematerialnych.

2. Przedsiębiorstwo powinno kierować się misją i wartościami - transparentność i autentyczność.

3. Dostawcy, reprezentujący stronę podażową na danej platformie, powinni być szanowani i wspierani, tak aby uczynić ich życie lepszym w warstwie ekonomicznej i społecznej.

4. Klienci, reprezentujący stronę popytową na platformie, powinni czerpać korzyść z możliwości dostępu do dóbr i usług w sposób bardziej efektywny, niż gdyby je nabywali na własność.

5. Przedsiębiorstwa powinny być budowane na rozproszonych rynkach i w zdecentralizowanych sieciach, które tworzą poczucie przynależności, zbiorowej odpowiedzialności i zbiorowych korzyści.

Doprecyzowanie myślenia o istocie ekonomii współpracy może odbyć się na drodze konfrontacji dwóch zasadniczych działań na rynku. Zasad współdzielenia i tradycyjnej wymiany rynkowej. Wyniki takiej konfrontacji zawiera tabela 2.

Tabela 2. Porównanie podstaw ekonomii współpracy - współdzielenia i tradycyjnej wymiany rynkowej

\begin{tabular}{|l|l|l|}
\hline \multicolumn{1}{|c|}{ Współdzielenie } & \multicolumn{1}{|c|}{ Wymiana rynkowa } & \multicolumn{1}{c|}{ Opis } \\
\hline $\begin{array}{l}\text { Nieobopólne } \\
\text { (jednostronne) }\end{array}$ & wzajemna, obopólna & $\begin{array}{l}\text { Brak obopólności, wzajemności nie jest } \\
\text { wymagany w ekonomii współpracy. Jest to ważny } \\
\text { element tradycyjnej wymiany rynkowej }\end{array}$ \\
\hline Więzi społeczne & brak więzi społecznych & $\begin{array}{l}\text { Dzielenie się tworzy pewne więzi społeczne. } \\
\text { Nie są one konieczne w przypadku wymiany } \\
\text { rynkowej }\end{array}$ \\
\hline Współwłasność & brak współwłasności & $\begin{array}{l}\text { Podczas dzielenia się obie strony czują się } \\
\text { odpowiedzialne za wykorzystywany przedmiot } \\
\text { (poczucie współwłasności). Nie jest tak } \\
\text { w przypadku tradycyjnej wymiany }\end{array}$ \\
\hline $\begin{array}{l}\text { Pieniądze nie są } \\
\text { istotne }\end{array}$ & pieniądze są istotne & $\begin{array}{l}\text { Dzielenie się nie zawsze wymaga transferu } \\
\text { śodków pieniężnych, tak jak to jest w przypadku } \\
\text { wymiany }\end{array}$ \\
\hline Zależne & niezależne & $\begin{array}{l}\text { Konsumpcja przez dzielenie się zależy od innych } \\
\text { zaangażowanych osób - zbiorowości, wymiana } \\
\text { jest niezależna }\end{array}$ \\
\hline Brak wyceny & wycena & $\begin{array}{l}\text { Precyzyjna wycena jest ważna w wymianie } \\
\text { rynkowej ze względu na możliwość określenia } \\
\text { kosztów }\end{array}$ \\
\hline $\begin{array}{l}\text { Mniejsze } \\
\text { możliwości kontroli } \\
\text { i regulacji }\end{array}$ & kontrola i regulacja & $\begin{array}{l}\text { Przez ramy prawne wymiana rynkowa jest } \\
\text { w większym stopniu poddana regulacji i kontroli, } \\
\text { np. służb podatkowych }\end{array}$ \\
\hline
\end{tabular}

Źródło: opracowanie własne na podstawie: Reza Habibi, Davidson, Laroche (2017: 115) 
W tym miejscu warto uszczegółowić próbę zrozumienia istoty ekonomii współpracy o klasyfikację usług, które wchodzą w jej zakres. Departament Gospodarki i Statystyki Stanów Zjednoczonych (U.S. Department of Commerce, 2016) zidentyfikował ponad 20 obszarów usługowych, w których obecne są założenia ekonomii współpracy. L. Gansky (Gansky, 2012) w książce pt. The Mesh zidentyfikowała 25 kategorii usług tego typu i ponad 9700 firm sieciowych rozmieszczonych w ponad 1630 miastach w ponad $130 \mathrm{kra}-$ jach. Najpopularniejszą próbą klasyfikacji jest plaster miodu ekonomii współpracy (honeycomb of collaborative economy) stworzony przez Jeremiaha Owyanga. Na jego podstawie powstała tabela przedstawiająca 16 kategorii i 44 podkategorii - funkcji usługowych obsługiwanych przez przedsiębiorstwa $z$ branży ekonomii współpracy.

Tabela 3. Kategorie i subkategorie usług związanych z sharing economy. Obszary działania ekonomii współpracy

\begin{tabular}{|c|c|c|c|}
\hline $\begin{array}{c}\text { Kategoria } \\
\text { (obszar) }\end{array}$ & Subkategoria & Platformy & $\begin{array}{c}\text { Element } \\
\text { modelu } \\
\text { Giffingera }\end{array}$ \\
\hline \multirow{3}{*}{$\begin{array}{l}\text { Analizowanie } \\
\text { i opiniowanie }\end{array}$} & planowanie podróży & Ridescout, What's the Fare & \multirow{3}{*}{1} \\
\hline & $\begin{array}{l}\text { ocena i reputacja } \\
\text { dóbr }\end{array}$ & $\begin{array}{l}\text { eRated, HireRight, Karma, Onfido, } \\
\text { Traity, TrustCloud, Veridu, Vijilent }\end{array}$ & \\
\hline & wynajem lokali & $\begin{array}{l}\text { Beyond Pricing, Everbooked, Kigo } \\
\text { (RateCoaster), Smart Host }\end{array}$ & \\
\hline \multirow{3}{*}{$\begin{array}{l}\text { Wsparcie } \\
\text { przedsiębiorstw } \\
\text { i organizacji }\end{array}$} & pośrednictwo pracy & Slice Rides, Twogo & \multirow{3}{*}{1} \\
\hline & platformy współpracy & $\begin{array}{l}\text { Button, Cloud Commerce Factory, } \\
\text { Crowdtap, eYeka, Innoverne, } \\
\text { Juggernaut, Marketplacer, Mila, } \\
\text { Nearme, Sharetribe, Tilt }\end{array}$ & \\
\hline & łańcuchy dostaw & Cargomatic, LocalMotion, WoNoLo & \\
\hline \multirow[t]{3}{*}{\begin{tabular}{|l} 
Żywność \\
\end{tabular}} & dostawa jedzenia & $\begin{array}{l}\text { Farmigo, GrubMarket, Saucey, } \\
\text { SpoonRocket, Sprig, UberEats }\end{array}$ & \multirow{3}{*}{$1,3,5$} \\
\hline & $\begin{array}{l}\text { dzielenie się } \\
\text { żywnością } \\
\end{array}$ & $\begin{array}{l}\text { Bon Appetour, Eatwith, Feastly, } \\
\text { Leftoverswap, Mealsharing, Vizeat }\end{array}$ & \\
\hline & $\begin{array}{l}\text { wspólne } \\
\text { przygotowywanie } \\
\text { posiłków }\end{array}$ & $\begin{array}{l}\text { Barnraiser, Kitchen Surfing, Kitchit, } \\
\text { Munchery, Rub \& Stub, The Food } \\
\text { Assembly }\end{array}$ & \\
\hline \multirow[t]{3}{*}{$\begin{array}{l}\text { Dobra } \\
\text { materialne }\end{array}$} & wypożyczanie & $\begin{array}{l}\text { Bagborrowsteal, Hey, Neighbor! Open } \\
\text { Shed, Peerby, Pley, RentTheRunway, } \\
\text { Rocksbox }\end{array}$ & \multirow{3}{*}{$1,3,4,5$} \\
\hline & $\begin{array}{l}\text { twórczość (ruch } \\
\text { twórców) }\end{array}$ & $\begin{array}{l}\text { Brit + Co, CustomMade, Make, Maker's } \\
\text { Row, Shapeways, Techshop, The } \\
\text { Grommet }\end{array}$ & \\
\hline & \begin{tabular}{|l|} 
dobra używane \\
(obrót)
\end{tabular} & $\begin{array}{l}\text { Kijiji, Moveloot, OfferUp, Poshmark, } \\
\text { TradeMe, Wallapop, Warplt, Yerdle }\end{array}$ & \\
\hline \multirow[t]{2}{*}{ Zdrowie } & $\begin{array}{l}\text { peer-to-peer } \\
\text { (wzajemna pomoc) }\end{array}$ & $\begin{array}{l}\text { Bemyeyes }{ }^{\star} \text { CoHealo, Crowdmed, } \\
\text { Helparound ( }{ }^{*} \text { np. pomoc niewidomym, } \\
\text { wymiana sprzętu rechabilitacyjnego) }\end{array}$ & \multirow[b]{2}{*}{4,5} \\
\hline & usługi opiekuńcze & $\begin{array}{l}\text { Curbside Care, Dispatch Health, Doctor } \\
\text { on Demand, Eaze, Heal, Medicast, } \\
\text { Medneo, MedZed, Pager, RetraceHealth, } \\
\text { Stat }\end{array}$ & \\
\hline
\end{tabular}




\begin{tabular}{|c|c|c|c|}
\hline \multirow[t]{3}{*}{ Nauka } & udostępnianie książek & Chegg, Sidewalk, Zookal & \multirow{3}{*}{4} \\
\hline & $\begin{array}{l}\text { instruktarz, } \\
\text { korepetycje }\end{array}$ & $\begin{array}{l}\text { Coursera, Khan Academy, SimpliLearn, } \\
\text { Thinkful, Udacity, Udemy }\end{array}$ & \\
\hline & peer-to-peer & $\begin{array}{l}\text { Gibbon, Instructables, Maven, P2P } \\
\text { University, Sharing Academy, Skillshare, } \\
\text { uTest }\end{array}$ & \\
\hline \multirow[t]{3}{*}{ Logistyka } & transport lokalny & $\begin{array}{l}\text { Deliv, Favor, Ghosttruck, Instacart, } \\
\text { Kanga, Lugg, Postmates, Shadowfax, } \\
\text { UberRUSH }\end{array}$ & \multirow{3}{*}{1,3} \\
\hline & shipping & $\begin{array}{l}\text { BellHops, Nimber, PiggyBee, Roadie, } \\
\text { Sheaply, Shipster, Shyp, Transfix }\end{array}$ & \\
\hline & magazynowanie & MakeSpace, Roost, Stashbee & \\
\hline \multirow[t]{5}{*}{$\begin{array}{l}\text { Przemieszczanie } \\
\text { społecznościowe } \\
\text { i parkowanie }\end{array}$} & $\begin{array}{l}\text { współpodróżowanie } \\
\text { (ride hailing) } \\
\text { (Valet services) }\end{array}$ & $\begin{array}{l}\text { BlaBlaCar, Bridj, Chariot, Didi Kuaidi, } \\
\text { Easy Taxi, Flywheel, Gett, Grab } \\
\text { (GrabTaxi), Hailo, Juno, Lazooz, Loup, } \\
\text { Lyft, OlaCar, RallyBus, Shuddle, Surfair, } \\
\text { TianTian, Uber, Wingz }\end{array}$ & \multirow{5}{*}{1,3} \\
\hline & \begin{tabular}{|l|} 
obsługa \\
i serwisowanie \\
\end{tabular} & $\begin{array}{l}\text { CARMAnation, Filld, YourMechanic, } \\
\text { Purple }\end{array}$ & \\
\hline & parking & \begin{tabular}{|l} 
JustPark, Park On My Drive, Parqex, \\
Roost, Rover, YourParkingSpace
\end{tabular} & \\
\hline & obsługa parkingowa & Caarbon, Luxe, Valetanywhere, ZIRX & \\
\hline & rowery & BCycle, BikeSharing, Splinlister & \\
\hline \multirow[t]{3}{*}{ Finanse } & crowdfunding & $\begin{array}{l}\text { Circle Up, Crowdfunder, Experiment, } \\
\text { FundingCircle, Gofundme, Indiegogo, } \\
\text { Kickstarter, OurCrowd, Pave }\end{array}$ & \multirow{3}{*}{1,4} \\
\hline & kryptowaluty & $\begin{array}{l}\text { Bitcoin, Coinbase, Dash, Litecoin, } \\
\text { Ripple }\end{array}$ & \\
\hline & pożyczanie pieniędzy & $\begin{array}{l}\text { Able, Faircent, Kiva, LendingClub, } \\
\text { Prosper, RateSetter, Zopa }\end{array}$ & \\
\hline \multirow[t]{2}{*}{ Usługi miejskie } & rowery miejskie & \begin{tabular}{|l|} 
Bicing Barcelona, Hangzhou Public \\
Bicycle, Santander Cycles London, Velib \\
\end{tabular} & \multirow{2}{*}{$1,2,3$} \\
\hline & $\begin{array}{l}\text { inne (np. wynajem } \\
\text { maszyn) }\end{array}$ & $\begin{array}{l}\text { Getable, MachineryLink, Munirent, } \\
\text { SeeClickFix, YardClub }\end{array}$ & \\
\hline \multirow[t]{2}{*}{ Usługi } & biznesowe & $\begin{array}{l}\text { 99Designs, Cloudpeeps, Crowdspring, } \\
\text { FieldAgent, Gigwalk, HourlyNerd, } \\
\text { Kaggle, Nabbesh, Payable, StaffJoy, } \\
\text { UniversalAvenue, UpCounsel, Upwork } \\
\end{array}$ & \multirow{2}{*}{1,5} \\
\hline & $\begin{array}{l}\text { osobiste (np. opieka } \\
\text { nad zwierzętami, } \\
\text { ogrodem) }\end{array}$ & $\begin{array}{l}\text { Airtasker, Ask for Task, Bannerman, } \\
\text { Care.com, DogVacay, Fancy Hands, } \\
\text { Fiverr, Musketeer, Taskrabbit, } \\
\text { WeGoLook, Zaarly } \\
\end{array}$ & \\
\hline \multirow[t]{2}{*}{$\begin{array}{l}\text { Noclegowe, } \\
\text { udostępnianie } \\
\text { miejsca }\end{array}$} & noclegi & $\begin{array}{l}\text { 9flats, Airbnb, CanadaStays, } \\
\text { Couchsurfing, Flipkey, hipcamp, } \\
\text { Homeaway, Homeexchange, HouseTrip, } \\
\text { Love HomeSwap, Nightswapping, } \\
\text { Onefinestay, Tujia, We are Pop Up, } \\
\text { Xiaozhu } \\
\end{array}$ & \multirow[t]{2}{*}{1} \\
\hline & przestrzeń do pracy & $\begin{array}{l}\text { Breather, CoPass, HiRise, Liąuidspace, } \\
\text { PeerSpace, Pivotdesk, Sharedesk, } \\
\text { Storefront, WeWork }\end{array}$ & \\
\hline
\end{tabular}




\begin{tabular}{|c|c|c|c|}
\hline \multirow[t]{2}{*}{ Urządzenia } & energia & $\begin{array}{l}\text { GridMates, Solar Mosaic, Vandebron, } \\
{ }^{\star} \text { Yeloha ( }{ }^{*} \text { udostępnianie dachu) }\end{array}$ & \multirow[t]{2}{*}{1} \\
\hline & telekomunikacja & Fon, Open Garden, Serval Project & \\
\hline \multirow{2}{*}{$\begin{array}{l}\text { Wynajem } \\
\text { środków } \\
\text { transportu }\end{array}$} & wynajem łodzi & Boatbound, Boatsetter, Sailo & \multirow[b]{2}{*}{1,2} \\
\hline & $\begin{array}{l}\text { wynajem } \\
\text { samochodów }\end{array}$ & $\begin{array}{l}\text { Atzuche, CambioCar, Car2Go, } \\
\text { DriveNow, easyCar Club, Flightcar, } \\
\text { Getaround, Scoot, Sharoo, Turo } \\
\text { (RelayRides),YongChe, Zipcar }\end{array}$ & \\
\hline \multirow[t]{2}{*}{$\begin{array}{l}\text { Zdrowie i uroda } \\
\text { (pielęgnacja) }\end{array}$} & uroda & $\begin{array}{l}\text { BeGlammed, Belita, GlamSąuad, } \\
\text { MyGlamm, Priv, Swipecast }\end{array}$ & \multirow{2}{*}{1,5} \\
\hline & zdrowie & $\begin{array}{l}\text { ClassPass, Coachup, Entrenaya, Kindly, } \\
\text { PopExpert, Vint, Zeel }\end{array}$ & \\
\hline \multirow{3}{*}{$\begin{array}{l}\text { Wsparcie } \\
\text { w pracy } \\
\text { i działalności } \\
\text { gospodarczej }\end{array}$} & ubezpieczenia & Friendsurance, Guevara, MetroMile & \multirow{3}{*}{1,4} \\
\hline & $\begin{array}{l}\text { zarządzanie } \\
\text { nieruchomościami }\end{array}$ & $\begin{array}{l}\text { GuestHop, Guesty, HostTonight, Pillow, } \\
\text { TurnKey Vacation Rentals }\end{array}$ & \\
\hline & współpraca branżowa & $\begin{array}{l}\text { Breeze, Freelancers Union, Peers.org, } \\
\text { SherpaShare, StrideHealth, Vugo }\end{array}$ & \\
\hline
\end{tabular}

Źródło: opracowanie własne na podstawie: Owyang (2014), Ganapatia, Reddickb (2018)

Problemem i coraz poważniejszym polem konfliktu staje się próba regulacji działalności gospodarczej wpisującej się w szerokie ramy ekonomii współpracy. Paradoksalnie ta dziedzina gospodarki w sposób innowacyjny i kreatywny wykorzystuje platformy cyfrowe komunikacji do efektywnego wykorzystywania wolnych zasobów, co można odczytać z tabeli 3. Z drugiej strony ekonomia współpracy tworzy nowe pola konfliktu i konkurencji dla podobnych działalności gospodarczych o tradycyjnym sposobie organizacji i ewolucji na rynku. Przykładem niech będzie usługa oferowana przez platformę Uber, polegająca na wykorzystaniu prywatnego samochodu do transportu osób za pomocą rezerwacji elektronicznej, która wywołuje protesty korporacji taksówkarskich. Polem konfliktu są koszty działalności taksówkarskiej oraz konkurencja cenowa po stronie kierowców Ubera. W wielu miejscach na świecie rządy oraz sądy interweniowały w podobnych sporach, ograniczając lub zakazując działalności gospodarczej w modelu ekonomii współpracy. Przykładem może być projekt ustawy o transporcie drogowym w Polsce. Problem ten widoczny jest także w przypadku przestrzeni w miastach - centra miast i atrakcyjne lokalizacje sukcesywnie zapełniają się lokalami w ofercie Airbnb i podobnych firm, co wpływa na lokalne rynki nieruchomości i powoduje wyparcie mieszkańców z atrakcyjnych turystycznie obszarów miast. Jednocześnie tradycyjna działalność hotelarska i hospitality staje wobec wyzwania konkurencji - często nieopodatkowanej (tabela 4). Przykładem jest korporacja Airbnb, której kapitalizacja dogania sieć hotelową Hilton i Marriott (Griswold, 2016).

Tabela 4. Porównanie dwóch sieci - hotelarskiej i peer-to-peer w branży hotelarskiej (2015)

\begin{tabular}{|l|l|}
\hline \multicolumn{1}{|c|}{ Hilton hotels \& resorts } & \multicolumn{1}{c|}{ Airbnb } \\
\hline Data założenia 1919 r. & Data założenia 2008 r. \\
680000 pokoi w 91państwach & 800 000 pokoi w 192 państwach \\
310000 pracowników & 600 pracowników \\
Wartość rynkowa 29,6 mld dol. & Wartość rynkowa 13 mld dol. \\
\hline
\end{tabular}

Źródło: opracowanie własne na podstawie Lu, Kandampully (2016) 
Ekonomia współpracy i różnice pomiędzy wymianą rynkową a współdzieleniem w czystej ideowej postaci zakładają marginalne znaczenie komercyjnych rozwiązań biznesowych i kierowania się zyskiem w tego typu działalności gospodarczej. Sharing economy podlega jednak grze rynkowej, a wartość firm pierwotnie zaczynających jako startupy, np. Ubera czy Airbnb, wzrasta. W ostatniej dekadzie wartość podmiotów działających w obszarze ekonomii współpracy rosła wykładniczo. Firma doradcza PriceWaterhouseCoopers w raporcie The sharing economy (PWC, 2015) szacuje, że z 15 mld dol. w 2014 r. wartość tych podmiotów wzrośnie do 335 mld dol. w roku 2025. Mamy więc do czynienia z dynamicznie rozwijającym się zjawiskiem w skali globalnej. Dostępnych jest wiele statystyk potwierdzających powyższe twierdzenia o szybkim wzroście udziału w rynku i wartości aktywów przedsiębiorstw powiązanych z ekonomią współpracy. Przykładem niech będzie rycina 2, prezentująca wzrost liczby gości korzystających z usług Airbnb w Londynie. Podobne wykresy o niemal wykładniczym wzroście publikują inne miasta $\mathrm{z}$ całego świata.

Trudno oszacować zamkniętą listę przedsiębiorstw działających wedle zasad sharing economy. W Europie liderami są Francja i Wielka Brytania z ponad 50 takimi przedsięwzięciami. W Niemczech, Holandii i Hiszpanii takich firm jest 25-50, a mniej niż 25 - w Szwecji, we Włoszech, Belgii i Polsce (Vaughan, Daverio, 2016). W Polsce pomimo niskiego poziomu zaufania społecznego powstają podmioty tego typu, często są to tzw. klony globalnych firm, takich jak BlaBlaCar, Uber. Przykładami mogą być takie polskie podmioty, jak: Skilltrade, Trejdoo, Kokos, Wolneauto.pl, JadeZabiore.pl, iParkomat, wooloo.pl, Otodojazd.

\section{Rola sharing economy w realizacji koncepcji Smart City}

Ekonomia współpracy ze względu na swoje szczególne cechy łączy się z koncepcją miast Smart City. Dzięki stworzeniu przyjaznego środowiska dla rozwoju i rozpowszechnienia się przedsiębiorstw ekonomii współpracy miasta mogą osiągać wiele spośród celów modelu koncepcji miasta inteligentnego. Powstają warunki sprzyjające postawom

Rycina 2. Zbiorcze zestawienie transakcji wynajmu na portalu Airbnb

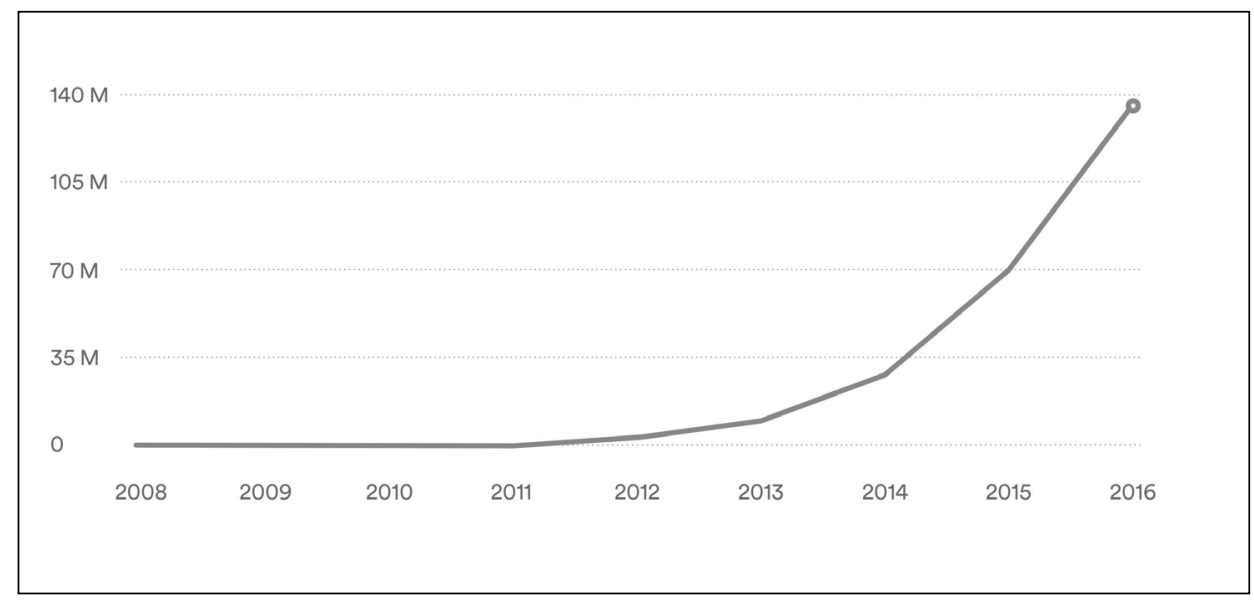

Źródło: Airbnb Policy Tool Chest (2019) 
przedsiębiorczym wśród mieszkańców. Miasta są naturalnym środowiskiem współpracy i współdzielenia, społecznym systemem terytorialnym. Pisał już o tym Z. Chojnicki (Chojnicki, 1989). Platformy internetowe pośredniczące w wymianie dóbr i usług w ekonomii współpracy najlepiej sprawdzają się w lokalnej społeczności i na stosunkowo krótkich dystansach. Komplementarność koncepcji inteligentnych miast i ekonomii współpracy zależy od podejścia władz miast do innowacji, wolności gospodarczej. Należy również zauważyć, że współdzielenie może pośrednio przyczynić się do gospodarczego sukcesu miasta. Odpowiednia polityka, sprzyjająca zjawiskom i aktywnościom oddolnym w obszarze ekonomii współpracy, przynosi korzyści mieszkańcom, ale może ograniczyć potencjalne wpływy podatkowe, gdyby np. aktywność ta była podejmowana w sposób tradycyjny.

Elementy modelu miasta inteligentnego odpowiadają obszarom działalności gospodarczej i aktywności społecznej związanym z gospodarką współpracy. Najczęściej jest to pierwszy obszar: inteligentna gospodarka (por. tabele 1 i 3), ale efekty działania mechanizmów sharing economy widoczne są $\mathrm{w}$ innych obszarach, np. pozwalają na oszczędność zasobów, co sprawia, że pośrednio zyskuje na tym środowisko przyrodnicze, czyli Smart Environment. Gospodarka/ekonomia współpracy wpływać może na jakość życia w mieście oraz na jakość jego zasobów ludzkich i społecznych, np. przez wpływ na kreatywność - obszary 4 i 5: inteligentne życie i inteligentni ludzie (usługi wymiany narzędzi twórczych, rękodzieła, uczenie się, współpraca). Łączenie kwestii ekonomicznych z problemami mobilności (obszary 1 i 2 z modelu Giffingera) określić można symbiozą, gdyż przynosi ono korzyści dwustronne. Przykładem może być czasowe użyczanie własnych pojazdów, co eliminuje puste przebiegi i nie wymaga przeznaczania znacznych środków finansowych na zakup prywatnych samochodów. Jednocześnie pozwala właścicielom lub firmom wypożyczającym swoją flotę lepiej wykorzystać samochody.

Ekonomia współpracy stanowi wyzwanie dla konkurujących z nią podmiotów. Powstaje tu pole konfliktu, w którym działalność gospodarcza regulowana tradycyjnymi normami prawnymi i regulacją instytucji państwowych staje się mniej konkurencyjna. Rodzi to zarzut nierównych zasad konkurencji. Z drugiej strony ekonomia współpracy aktywizuje osoby do tej pory nieuczestniczące w grze rynkowej, pozwala oszczędzać zasoby, uzupełnia w sposób elastyczny braki i wiąże się z wolnością gospodarczą. Elementy miasta Smart City i zakres współpracy sieciowej i uspołecznionej mieszkańców zaprezentowano w tabeli 5.

Tabela 5. Elementy miasta Smart City i zakres współpracy sieciowej i uspołecznionej mieszkańców

\begin{tabular}{|l|l|}
\hline \multicolumn{1}{|c|}{$\begin{array}{c}\text { Potencjalne rozwiązania w miastach } \\
\text { inteligentnych }\end{array}$} & \multicolumn{1}{|c|}{$\begin{array}{c}\text { Przedsiębiorczość i aktywność związana } \\
\text { z gospodarką współpracy }\end{array}$} \\
\hline $\begin{array}{l}\text { Energia odnawialna - nowe źródła energii, } \\
\text { takie jak ogniwa fotoelektryczne i energia } \\
\text { wiatru i wody }\end{array}$ & $\begin{array}{l}\text { Mieszkańcy miast jako prosumenci } \\
\text { produkujący energię dla siebie i odsprzedający } \\
\text { ją do sieci }\end{array}$ \\
\hline $\begin{array}{l}\text { Partycypacja - obywatele, przedsiębiorstwa } \\
\text { prywatne, instytuty i organizacje publiczne, } \\
\text { które tworzą ekosystem w celu twórczego } \\
\text { rozwiązywania problemów społecznych }\end{array}$ & $\begin{array}{l}\text { Wykorzystanie mediów społecznościowych, } \\
\text { systemów głosowania i narzędzi demokracji } \\
\text { lokalnej. }\end{array}$ \\
\hline $\begin{array}{l}\text { Crowdfounding - sposób finansowania } \\
\text { projektów, inicjatyw i nowo powstających } \\
\text { przedsiębiorstw }\end{array}$ & $\begin{array}{l}\text { Wspieranie lokalnych inicjatyw, zbiórki } \\
\text { celowe, pomoc potrzebującym }\end{array}$ \\
\hline
\end{tabular}




\begin{tabular}{|l|l|}
\hline $\begin{array}{l}\text { Ekonomia współpracy - wykorzystywanie } \\
\text { technologii informacyjnej jako czynnika } \\
\text { umożliwiającego łączenie podaży i popytu } \\
\text { w nowy sposób. Korzystanie z platform } \\
\text { cyfrowych, aby udostępniać i wykorzystywać } \\
\text { nadmiar towarów i rzeczy }\end{array}$ & $\begin{array}{l}\text { Realizowanie takich celów, jak: zmniejszenie } \\
\text { zużycia zasobów, oszczędność, inkluzja } \\
\text { społeczna, wyrównywanie szans, pobudzanie } \\
\text { przedsiębiorczości }\end{array}$ \\
\hline $\begin{array}{l}\text { Grywalizacja - wykorzystanie myślenia } \\
\text { i elementów projektowania gier. Celem } \\
\text { grywalizacji jest zachęcenie ludzi do zmiany } \\
\text { ich zachowania }\end{array}$ & $\begin{array}{l}\text { Gry miejskie, Geo Cahsing, Pokemon Go, Geo } \\
\text { Tagging }\end{array}$ \\
\hline $\begin{array}{l}\text { Samoorganizacja - proces, w którym } \\
\text { ogólny ład społeczny wynika z lokalnych } \\
\text { interakcji między ludźmi w początkowo } \\
\text { nieuporządkowanym systemie. Jest } \\
\text { spontaniczny i niekontrolowany }\end{array}$ & $\begin{array}{l}\text { Wspólne działania w obszarze kultury, polityki, } \\
\text { manifestacji przekonań, protestów i poparcia, } \\
\text { samopomocy }\end{array}$ \\
\hline $\begin{array}{l}\text { Chmura i Big Data - dostęp na żądanie } \\
\text { do bogatej funkcjonalności aplikacji, mocy } \\
\text { obliczeniowej i przestrzeni na dane. Duże } \\
\text { ilości bardzo zmiennych i bogatych danych } \\
\text { (dane strukturalne, dane z czujników, audio, } \\
\text { wideo i in.) }\end{array}$ & $\begin{array}{l}\text { Udostępnianie danych statystycznych } \\
\text { i graficznych, naukowych, ebooków, książek } \\
\text { i archiwów mieszkańcom w celach naukowych, } \\
\text { poszerzania wiedzy. }\end{array}$ \\
\hline $\begin{array}{l}\text { Smartfony - mobilny internet, zaawansowane } \\
\text { urządzenia mobilne i aplikacje z intuicyjnymi } \\
\text { interfejsami działające jako front end dla wielu } \\
\text { innowacyjnych rozwiązań }\end{array}$ & $\begin{array}{l}\text { Podstawowe urządzenia do komunikacji } \\
\text { i płatności w mieście. Aplikacje } \\
\text { społecznościowe służące do zgłaszania } \\
\text { zagrożeń i przestępstw, monitoringu } \\
\text { środowiska naturalnego }\end{array}$ \\
\hline $\begin{array}{l}\text { Media społecznościowe i platformy } \\
\text { internetowe }\end{array}$ & $\begin{array}{l}\text { Prawdopodobne wzmacnianie więzi } \\
\text { społecznych, poczucia tożsamości, } \\
\text { usieciowienie }\end{array}$ \\
\hline
\end{tabular}

Źródło: opracowanie własne

Miasta inteligentne nie są statycznym konceptem, lecz konceptem, który będzie ulegał przemodelowaniu, gdyż nie jesteśmy w stanie określić drogi postępu technologicznego i implikacji społecznych, które on wywoła. Pewnej próby spojrzenia w przyszłość i takiego, nieco futurystycznego spojrzenia, dokonał J. Owyang. W jego koncepcji pięciu er cyfrowego świata (Owyang, 2019) ekonomia współpracy zajmuje trzecią pozycję po erze internetu 2.0 (WEB 2.0). Era internetu to wymiana informacji w sposób jednostronny, w latach 90. XX w. nazywana była erą dotkomów (dot com), a zakończył ją głęboki branżowy kryzys. Kolejna era to social media i WEB 2.0. internetu, którego twórcami stali się sami użytkownicy, a np. marketerzy dostali narzędzia do bezpośredniego dotarcia do klientów. Obecnie przeżywamy trzecią erę - rozwoju ekonomii współpracy, w której ludzie otrzymali możliwość uzyskania od siebie tego, czego potrzebują. Kolejną erą wg Owyanga będzie era świata autonomicznego. Obecnie rozwiązania techniczne tej ery są w fazie testów. Czwarta era może zagrozić części działań gospodarczych ekonomii współpracy, gdyż wsparcie społeczne i współdzielenie będzie wypierane przez rozwiązania autonomiczne, np. autonomiczne taksówki, wsparcie sztuczną inteligencją usług okołobiznesowych i doradczych. Piąta era to era nowoczesnego dobrobytu, w której ciała i umysły ludzi oraz ich otoczenie będą wspierane przez zaawansowaną technologię. 


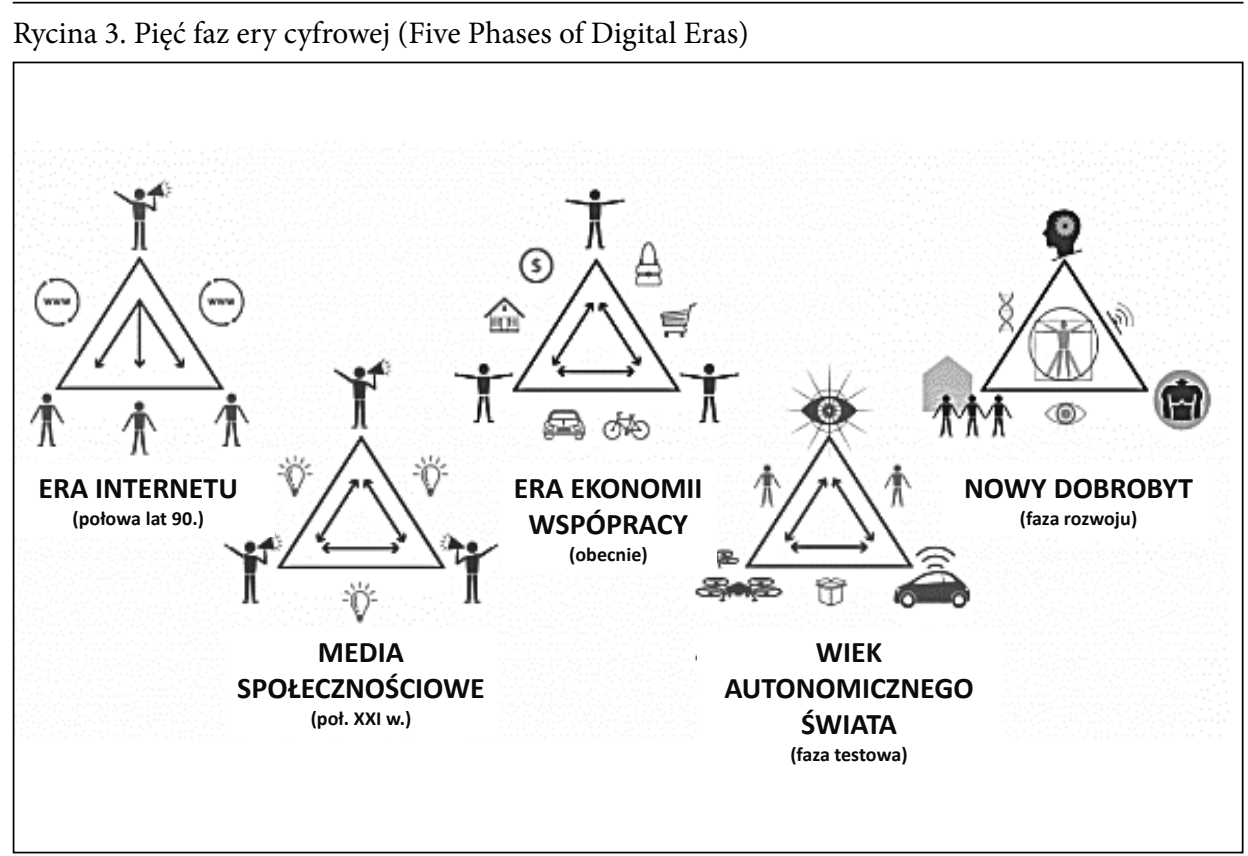

Źródło: Owyang (2019)

\section{Podsumowanie}

W odpowiedzi na zamieszczone we wstępie pytania badawcze można stwierdzić, że fenomen ekonomii współpracy w jej współczesnej wersji polega na wykorzystaniu nowych technologii komunikacyjnych w odbudowie i rozszerzeniu naturalnych dla lokalnych społeczności możliwości wymiany dóbr i usług, pomocy i racjonalizacji wykorzystania własnych zasobów ekonomicznych. Sharing economy daje nie tylko gratyfikacje materialne podmiotom i osobom, ale także „bonus” społecznościowy.

Gospodarka współpracy znajduje możliwości rozwoju w wielu obszarach rynku, głównie w usługach, konkuruje z powszechnym typem własności indywidualnej na rzecz czasowego korzystania z dóbr, zbiorowych zakupów, elastycznych form pracy i wykorzystania zasobów do tej pory niewykorzystanych, np. wolnych mieszkań, maszyn i urządzeń, osobistych uzdolnień i nadmiaru czasu. Ekonomia współpracy i związane z nią usługi mają znaczący udział w budowaniu miast zgodnych z koncepcją miasta inteligentnego. Miast Smart City trzeciej generacji, w których technologia jest tylko narzędziem wspierającym realizacje ludzkich potrzeb, w tym potrzeb z wyższych pozycji piramidy Maslova. W pewien sposób usługi i działania społecznościowe będą substytucyjne i konkurencyjne dla rozwiązań stricte technicznych. Można sobie wyobrazić, że zamiast działania czujnika w przestrzeni miejskiej, o zagrożeniu np. smogiem informować będą sami mieszkańcy przez specjalną aplikację z geolokalizacją (tak już się dzieje w Polsce). Nowoczesne technologie, infrastruktura ICT i oferowane przez nią usługi oraz platformy komunikacji stanowią produkty komplementarne dla ekonomii współpracy. Zakres ekonomii współpracy będzie zależny od tradycyjnych zasobów ludzkich i kapitału społecznego w mieście. Mieszkańcy miast sami zdecydują, w którą stronę będą woleli pójść, organizując swoje 
miejsce do życia w Smart City - w stronę większego uspołecznienia, czy też oddadzą naturalną dla istot społecznych potrzebę w pośrednictwo technologii. Przed władzami miast, a także organami prawodawczymi i regulatorami, stoi niełatwe zadanie pogodzenia obu form przedsiębiorczości: tradycyjnej formy wymiany rynkowej i form znanych ekonomii współpracy. Należy w tym przypadku rozpoznać, w jakim stopniu działalność w ekonomii współpracy to oddolne działanie mieszkańców miast, a w jakim - wykorzystanie ich aktywności przez nowe podmioty korporacyjne o rozproszonej strukturze organizacyjnej i niejasnym powiązaniu przestrzennym.

Literatura

References

Airbnb Policy Tool Chest. (2019; 15 listopada). Pozyskano z: https://www.airbnbcitizen.com/wp-content/ uploads/2016/12/National_PublicPolicyTool-ChestReport-v3.pdf

Albino, V., Berardi, U., Dangelico, R.M. (2018). Smart cities: definitions, dimensions, and performance. Journal of Urban Technology, 22(1), 1723-1738.

Azkuna, I. (2012). Smart Cities Study. International study on the situation of ICT, innovation and Knowledge in cities. Bilbao: The Committee of Digital and Knowledge-based Cities of UCLG.

Botsman, R. (2015; 2019, 1 stycznia). Defining the Sharing Economy: What is Collaborative Consumption - And What isn't?. Pozyskano z: https://www.fastcompany.com/3046119/defining-the-sharing-economy-what-is-collaborative-consumption-and-what-isnt

Botsman, R., Rogers, R. (2010). What's Mine is Yours. The Rise of Collaborative Consumption. New York: HarperCollins.

Chase, R. (2015). How People and Platforms Are Inventing the Collaborative Economy and Reinventing Capitalism. New York: Public Affairs.

Chojnicki, Z. (1989). Koncepcja terytorialnego systemu społecznego. Przegląd Geograficzny, 60(3), 491510.

Cohen, B. (2014; 2019, 1 stycznia). The Top 10 Smart Cities on the Planet. Pozyskano z: https://www. fastcompany.com/3038765/the-smartest-cities-in-the-world

Cohen, B. (2015; 2019, 1 lutego). The 3 Generations Of Smart Cities. Inside the development of the technology driven city. Pozyskano z: https://www.fastcompany.com/3047795/the-3-generations-of-smart-cities

Lu, C., Kandampully, J. (2016). What drives customers to use accessbased sharing options in the hospitality industry?, Research in Hospitality Management, 6(2), 119-125.

Deloitte. (2015; 2019, 1 lutego). Smart Cities. How rapid advances in technology reshaping our economy and society. Version 1.0. Pozyskano z: https://www2.deloitte.com/tr/en/pages/public-sector/articles/smart-cities.html

De Santis, R., Fasano, A., Mignolli, N., Villa, A. (2014). Smart City: fact and fiction. MPRA. Pozyskano z: https://mpra.ub.uni-muenchen.de/54536/1/MPRA_paper_54536.pdf

Ganapati, S., Reddick, C.G. (2018). Prospects and challenges of sharing economy for the public sector. Government Information Quarterly, 35, 77-87.

Gansky, L. (2012). The Mesh: Why the Future of Business Is Sharing. New York: Portfolio Penguin.

PWC. (2015). The Sharing Economy. Consumer Intelligence Series. The Sharing Economy. Pozyskano z: https://www.pwc.fr/fr/assets/files/pdf/2015/05/pwc_etude_sharing_economy.pdf

Gavaldà, J., Ribera, R. (2012). Barcelona 5.0: From Knowledge to Smartness? Working Paper Series, WP12-002. Barcelona: Universitat Oberta de Catalunya.

Giffinger, R., Haindlmaier, G. (2010). Smart Cities Ranking: an Effective Instrument for the Positioning of Cities? ACE: Architecture, City and Environment, 4, 6-26. 
Gotlibowska, K. (2018). Propozycja modelu miasta inteligentnego (Smart City) opartego na zastosowaniu technologii informacyjno-komunikacyjnych w jego rozwoju. Rozwój Regionalny i Polityka Regionalna, 42, 67-80.

Griswold, A. (2016; 2019, 15 stycznia). Airbnb's valuation exceeds that of every major hotel chain. Pozyskano z: https://www.theatlas.com/charts/HyjvbqfD

Ishida, T. (2017). Digital City, Smart City and Beyond. Conference Paper. Pozyskano z: https://www. researchgate.net/publication/317033563_Digital_City_Smart_City_and_Beyond

Martin, C.J., Upham, P., Budd, L. (2015). Commercial orientation in grassroots social innovation: insights from the sharing economy. Ecological Economics, 118, 240-251.

McLaren, D., Agyeman, J. (2015). Sharing Cities: A Case for Truly Smart and Sustainable Cities. Cambridge: MIT Press.

Mierzejewska, L. (2015). Zrównoważony rozwój miasta - wybrane sposoby pojmowania, koncepcje i modele. Problemy Rozwoju Miast, XII, 5-11.

Muñoz, P., Cohen, B. (2017). Mapping out the sharing economy: A configurational approach to sharing business modeling, Technological Forecasting and Social Change, 125, 21-37.

Owyang, J. (2014; 2019, 1 lutego). Framework: Collaborative Economy Honeycomb. Pozyskano z: http:// www.web-strategist.com/blog/2014/05/05/framework-collaborative-economy-honeycomb-osfest14Owyang, J. (2019, 1 lutego). Roadmap: Five Phases of Digital Eras. Pozyskano z: http://www. web-strategist.com/blog

Ramaprasad, A., Sánchez-Ortiz, A., Syn, T. (2017). A Unified Definition of a Smart City. In: Janssen M. et al. (red.) Electronic Government. EGOV 2017. Lecture Notes in Computer Science, 10428.

Renken, K., Schor, J. (2017). Putting the sharing economy into perspective. Environmental Innovation and Societal Transitions, 23, 3-10.

Reza Habibi, M., Davidson, A., Laroche, M. (2017). What managers should know about the sharing economy. Business Horizons, 60, 113-121.

Selloni, D. (2017). CoDesign for Public-Interest Services. Research for Development. Cham: Springer International Publishig AG.

Smart Cities Council, portal internetowy: https://smartcitiescouncil.com/

Smart Cities. Ranking of European medium-sized cities. Final report Edited by the Centre of Regional Science. (2007). Vienna UT. Pozyskano z: http://www.smart-cities.eu/download/smart_cities_final_report.pdf

Stokes, K., Clarence, E., Anderson, L., Rinne, A. (2014). Making Sense of the UK Collaborative Economy. Pozyskano z: www.collaboriamo.org/media/2014/10/making_sense_of_the_uk_collaborative_ economy_14.pdf

U.S. Department of Commerce, Economics and Statistics Administration, Office of the Chief Economist (ESA). (2016). Digital matching firms: A new definition in the "sharing economy": space. ESA Issue Brief, 1-16. Pozyskano z: http://www.esa.gov/sites/default/files/digital-matching-firms-new-definition-sharing-economy-space.pdf

Vaughan, R., Daverio, R. (2016). Assessing the size and presence of the collaborative economy in Europe. Pozyskano z: http://ec.europa.eu/DocsRoom/documents/16952/attachments/1/translations/en/ renditions/native

Jacek Rudewicz, dr inż., Uniwersytet Szczeciński, Instytut Geografii Społeczno-Ekonomicznej i Gospodarki Przestrzennej. Autor jest adiunktem w Zakładzie Badań Miast i Regionów. Ukończył kierunek geografia ze specjalnością geografia społeczno-ekonomiczna, kierunek zarządzanie i marketing oraz ekonomia. Obronił doktorat pt. Rozwój zrównoważony wielkich miast w Polsce. W pracy naukowej zajmuje się studiami miejskimi, rozwojem zrównoważonym, rozwojem regionalnym, teorią systemów.

Jacek Rudewicz, PhD, Eng, University of Szczecin, Institute of Socio-Economic Geography and Spatial Management. He has graduated from Geography with a specialisation in socioeconomic geography. He also holds a degree in management and marketing and economics. He is an assistant 
professor in Regional and Urban Studies Unit. His PhD thesis was entitled "Sustainable development of the Polish major cities". His research interests focus on wide urban studies, sustainable development, regional development, systems theory.

ORCID: 0000-0002-2659-4754

Adres/Address:

Uniwersytet Szczeciński

Instytut Gospodarki Przestrzennej i Geografii Społeczno-Ekonomicznej

Wydział Ekonomii Finansów i Zarządzania

ul. A. Mickiewicza 18, p.17

70-383 Szczecin, Polska

e-mail: jacek.rudewicz@usz.edu.pl 